\title{
Hermeneutic Approach to Teaching Schoolchildren to Read
}

\author{
Lyudmila Aleksandrovna Belyaeva \\ Doctor of Philosophy, Professor \\ Ural State Pedagogical University \\ Ekaterinburg, Russia \\ labelyaeva278@mail.ru
}

\author{
Irina Grigorevna Chugaeva \\ Candidate of pedagogical sciences \\ Ural State Pedagogical University \\ Ekaterinburg, Russia \\ irinachugaeva555@mail.ru
}

\author{
Elena Viktorovna Berezhnova \\ Doctor of Education, Associate Professor \\ Moscow State Institute of International Relations (University) of the Ministry of Foreign Affairs \\ National Research Moscow State University of Civil Engineering \\ Moscow, Russia \\ lina164@yandex.ru
}

\begin{abstract}
The article is devoted to the problem of valuesemantic reading by schoolchildren of literary and artistic works. The analysis of modern scientific and methodological literature showed the need to strengthen the axiological and communicative functions of reading, the authors' efforts are directed at solving these problems. The methodological basis of the study is the philosophical hermeneutics and its rules for understanding and interpreting texts. The result of the study is the pedagogical technology of value-semantic reading of literary and artistic work by students developed by the authors on the basis of philosophical hermeneutic and didactic communication.
\end{abstract}

Keywords - philosophical hermeneutics, understanding pedagogy, models of understanding, didactic communication, literary text.

\section{INTRODUCTION}

The improvement of modern humanitarian education is associated with the need to enhance the value-semantic and communicative functions of reading fiction by schoolchildren, which would help them to acquire new knowledge, understanding the world and the characteristics of their own personality, their role and significance in the world, and value self-determination.

The work of many authors is devoted to the problem of teaching schoolchildren to read; we especially note the publications of recent years concerning the problem of teaching semantic reading: L.V. Gorbul [1], L.N. Makarova [2], S.M. Mashaeva [3], A.I. Savost'yanov [4], D.Y. Pulatova, Sh. Honboboeva [5]. The work of E.A. Budoyan was eespecially interesting in the light of the subject of our study [6].

We note the particular importance of the communicative function of reading to enhance the reader's activity of adolescents. During an empirical study, V.G. Reef., E.A. Poleva found that in the process of philological education, younger adolescents (fifth graders) want to discuss books of interest to their peers and teachers. Moreover, the teacher is a more preferred participant in communication than the parent. In the teacher, students want to see an interesting conversationalist, able to understand their interests and opinions. The authors concluded in the course of the study that "children need their favorite works to be interpreted together with the teacher, so that other children can read them" [7].

N.M. Svirina in his study speaks about the lack of dialogue in the process of philological education of modern adolescents. She notes such shortcomings in reading as inattention of students to the author of the book, inability to convey the main content and comprehend what they read: "A modern student cannot enter into a full-fledged dialoguecontact with a writer (poet), for he is not taught to think by establishing causal relationships, but where is there to think figuratively?!" [8]. Indeed, artistic-figurative thinking is associated with the value aspect of a human being. It is known that the essential feature of artistic thinking is the unity of knowledge and evaluation. At the same time, the perception of a literary text begins on a sensual level, is associated with aesthetic experience, interest in the object, and in the future, with speculation and building up an artistic image, comprehension, enrichment of personal experience and understanding of life.

\section{METHODOLOGY}

The methodological basis for the development of valuesemantic reading is, in our opinion, philosophical hermeneutics (W. Dilthey, M. Heidegger, G.G. Gadamer). Thanks to W. Dilthey, the methodological status of hermeneutics was substantiated, principles for understanding the text adequate to the humanities studying the spiritual culture of the people, reflected in the language, were developed [9].

The meaning of language in the process of understanding was vividly and deeply characterized by $\mathrm{M}$. Heidegger. $\mathrm{He}$ 
sees language as a "tale" that addresses a person and through a person. For the process of understanding to take place, a person needs to learn to hear a "tale" (language), "be obedient to a tale", go towards him in the process of speaking [10]. G.G. Gadamer wrote about the relationship between himself and the text in the process of reading and analyzing a work of art as a necessary condition for understanding. One of the features of hermeneutics, in his opinion, is the comprehension of the literary text "for the sake of its beauty and truth" [11].

We are close to the position of F. Schleiermacher [12], which determines the position of hermeneutic knowledge not yet as a science, but as an art. By this, he emphasizes the irreducibility of hermeneutics to a simple mechanical description and the "sum of observations": it is the art of correctly expressing one's thoughts, correctly retelling someone else's speech and correctly understanding someone else's speech, and the third knowledge is mediating between the first and second. Understanding, according to $F$. Schleiermacher, is the dialectic of grammatical and psychological interpretation, where the grammatical interpretation is associated with the analysis of the original in the language (understanding speech as "taken out of the language"), and understanding speech as a fact in a thinking person ("developing spirit").

Moreover, hermeneutic success is associated with the discovery of the identity between language and thinking, that is, the solution to the problem will be absolute when "each side will be developed separately so that the development of the other side will not cause any change in the result." The author, in the process of understanding, suggests resorting to various hermeneutical techniques: objective assimilation (study of the language by the modern author, his historical era, a compilation of the "author's dictionary"), subjective assimilation (study of the author's "inner and outer life", circumstances of his life, his education, kind classes, etc.) [12].

F. Schleiermacher in a special way understands the relationship between the private and the whole (the "hermeneutic circle") as following the rule, according to which, understanding should begin with a "presentiment of the whole." To begin the movement in the hermeneutic circle, the researcher (reader) must proceed in his reasoning from a certain starting point. Such a starting point is the "cursor reading", which consists in the fact that "reading an excerpt of the text, wishing to understand the meaning of this passage, the interpreter proceeds from a certain hypothesis regarding the meaning of individual words and expressions, he intuitively guesses "their meaning" [13]

Further, when perceiving the next passage of the text, the researcher corrects his first preliminary understanding, thereby creating some new, more adequate anticipation of the whole and continues throughout his work on the work. As a result, on the one hand, the interpreter moves from the whole, which is intuitively understood, to the understanding of individual parts, and on the other hand, he corrects the general meaning based on the analysis of these parts. The principles of understanding texts developed by philosophical hermeneutics make it possible to gain an understanding of the meaning of a work of art, an understanding of the world and the characteristics of one's own personality, one's role and significance in the world, and value self-determination.

Thus, relying on a hermeneutic approach makes it possible to define "understanding of a literary text by a schoolchild reader" as a process of correlating the value-semantic content of a work of art with itself, with its personal experience, and involves the judgment of the student-reader on the content of a literary work, expression of his own opinion in the process of didactic communication.

\section{DISCUSSION AND RESULTS}

Under the didactic communication in the framework of a communicative-creative model of education, we understand: "interpersonal communication in the space-time continuum of sociocultural fields aimed at understanding and mutual understanding" [14]. Based on a dialogue, it is aimed at helping to achieve and develop a student's value-semantic relationship with the world of artistic reality, the author of a work of art, with himself, a teacher and classmates. Didactic communication activates the process of the birth of new knowledge, understanding and self-understanding in the process of dialogue.

It is especially important for us to emphasize that the purpose of the dialogue is to establish value-semantic relations, that is, the emergence of "appeal to each other". According to M. Buber: "The dialogue is not limited to the communication of people with each other, it, as we have seen, is the relationship to each other, expressed in communication. It follows that even if you can do without words, without communication, one thing must in any case be present in the dialogue - the mutual orientation of the action. The two people participating in the dialogue should obviously be facing each other, should be - anyway with what measure of activity or consciousness of activity - they are facing each other" [15]. The dialogue is not connected with observing a person and not with the contemplation of a person, but with penetration, that is, with the word: "it is only certain that a word has been addressed to me that requires an answer". Penetration is possible if a person proceeds from the reality of his being, understands his reality, for an ordered world is not a world order: "in order to meet the other, you need to have a starting point, to be at home". One must also learn to think of the existing Other, in the concreteness of its world, its reality. And art teaches this, because by its nature it is dialogical [15]

The same idea is developed by M. Heidegger He defines art not as an external object that we could look at from the side, but as an area of being in which we could exist. The task of the listener, viewer, reader is to be able to enter the space of art, to enable art to completely capture us [16].

In the process of entering into the world of readers of literary works, refer to the artistic image, the establishment of value-semantic relations important mission of the teacher. In our opinion, it is akin to "the art of the midwife," Socrates. The teacher helps the student when he creates knowledge hidden in the depths of his soul. Through questions and listening to answers, he prepares the birth of personal knowledge. Plato in his "Dialogue", describing the method of 
maieutics Socrates says that wisdom is not a simple transfer of property. It can not "flow, as soon as we touch each other, because the one who is full of it, to the one who is empty, as the water flows on the woolen thread from a full container to empty" Truth need to hear from their own lips, then this knowledge will be for a man of his personal knowledge. In this connection, Another is needed, in the process of dialogue with which this new personal knowledge is born.

TABLE I EMPATHIC VALUE TUNING. ENTRY INTO THE HERMENEUTIC CIRCLE

\begin{tabular}{|c|c|c|c|}
\hline $\begin{array}{c}\text { Didactic } \\
\text { communication } \\
\text { and its purpose }\end{array}$ & Activities & Result & Methods \\
\hline $\begin{array}{l}\text { "I and the world } \\
\text { of artistic } \\
\text { reality": } \\
\text { anticipation of } \\
\text { the idea of a } \\
\text { work of art as a } \\
\text { generalization } \\
\text { of the } \\
\text { emotionally- } \\
\text { figurative } \\
\text { content of a } \\
\text { work of art. The } \\
\text { scope of the } \\
\text { work of art is } \\
\text { holistic } \\
\text { (entrance to the } \\
\text { "hermeneutic } \\
\text { circle"). }\end{array}$ & $\begin{array}{l}\text { An empathic } \\
\text { attitude to the } \\
\text { perception of a } \\
\text { work of art, the } \\
\text { first attempt to } \\
\text { determine the } \\
\text { meaningful and } \\
\text { semantic } \\
\text { integrity of a } \\
\text { work of art. } \\
\text { Hypothesis. }\end{array}$ & $\begin{array}{l}\text { The } \\
\text { dialogue/polylo } \\
\text { gue of students } \\
\text { about the main } \\
\text { idea of the } \\
\text { work, the } \\
\text { exchange of } \\
\text { impressions, the } \\
\text { activation of } \\
\text { students' desire } \\
\text { to clarify the } \\
\text { author's value- } \\
\text { semantic } \\
\text { attitudes } \\
\text { through the } \\
\text { analysis of the } \\
\text { artistic and } \\
\text { expressive } \\
\text { means of the } \\
\text { language. }\end{array}$ & $\begin{array}{l}\text { Sample tasks: } \\
\text { - } \\
\text { composition- } \\
\text { saying "I } \\
\text { experienced } \\
\text { (a) and } \\
\text { anticipated } \\
\text { (a), th ...."; } \\
\text { - discussion } \\
\text { "the author's } \\
\text { lesson, in my } \\
\text { opinion, is } \\
\text { that ...."; } \\
\text { - essay- } \\
\text { reflection } \\
\text { "the world } \\
\text { created by the } \\
\text { author is } \\
\text { different in } \\
\text { that ..." }\end{array}$ \\
\hline
\end{tabular}

The initial component of didactic communication is the students' sensory perception of the work of art, the emotional response, the experience caused by reading the work of art. This state is possible with the activation of value-semantic relations "I am the world of artistic reality." For this, reading a work of art must begin with an "empathic setting". The teacher uses methods and techniques that activate empathy, reinforces students' desire to focus on artistic perception, arouses interest in a work of art, and the desire to build subsequent interaction on the emotional exchange of communication subjects with impressions of a work of art. In literature lessons, the teacher needs to create an atmosphere of openness, the acceptance of the personal opinion of each student, and the student to be responsible in their statements, based on personal value-semantic attitudes.

The multidimensionality of the main idea of a work of art leads to the need to determine the author's position, the characteristics of his thinking, which, in turn, are reflected in the language. Thus, the second stage of didactic communication is associated with the activation of valuesemantic relations "I am the author of a work of art." The student should see the image of the world of a specific person behind the image of the world in an artwork and take an understanding-dialogical attitude towards him. At the stage of artistic communication "I am the author of a work of art", the reader enters the hermeneutic circle and moves to clarify the meaning, making cyclic movements from the whole (comprehension of the idea) to the part and from parts to the whole.

At this stage of didactic communication, students are actively seeking information about the personality traits of the author of the work of art, the historical era, the ideals of that time regarding the problem raised by the author. At the same time, the identity of the author of the work of art is for the reader "Significant Other", with whom to build a dialogue.

TABLE II MOVEMENT IN THE HERMENEUTIC CIRCLE. CLARIFICATION OF MEANINGS

\begin{tabular}{|c|c|c|c|}
\hline $\begin{array}{c}\text { Didactic } \\
\text { communication } \\
\text { and its purpose }\end{array}$ & Activities & Result & Methods \\
\hline $\begin{array}{l}\text { "I and the } \\
\text { author of a } \\
\text { work of art": } \\
\text { recreation of the } \\
\text { author's } \\
\text { linguistic } \\
\text { picture, } \\
\text { understanding } \\
\text { of the problem } \\
\text { that the author } \\
\text { is trying to } \\
\text { solve, the } \\
\text { originality of } \\
\text { his solution }\end{array}$ & $\begin{array}{l}\text { Poetic and } \\
\text { linguistic } \\
\text { analysis of the } \\
\text { text, aimed at } \\
\text { reconstructing } \\
\text { the author's } \\
\text { picture of the } \\
\text { world, the } \\
\text { system of } \\
\text { spiritual values } \\
\text { of the writer } \\
\text { (poet), his } \\
\text { assessment of } \\
\text { reality }\end{array}$ & $\begin{array}{l}\text { Understandin } \\
\mathrm{g} \text { by the } \\
\text { student- } \\
\text { readers of the } \\
\text { author's } \\
\text { identity in the } \\
\text { context of the } \\
\text { "I am Other" } \\
\text { relationship, } \\
\text { adoption of a } \\
\text { dialogical } \\
\text { position }\end{array}$ & $\begin{array}{l}\text { - use of the } \\
\text { biographical } \\
\text { method } \\
\text {-creating a socio- } \\
\text { psychological } \\
\text { portrait of the } \\
\text { author of a literary } \\
\text { text. } \\
\text { debate on the } \\
\text { topic: "What } \\
\text { copyright values } \\
\text { do I accept for } \\
\text { myself?" } \\
\text { - proposal of } \\
\text { another name for } \\
\text { a work of art an } \\
\text { explanation of } \\
\text { personal position }\end{array}$ \\
\hline
\end{tabular}

We note that in the process of modeling the peculiarities of the author's thinking, the reader "should not abstract from himself and from the situation (vital, historical, cultural, social) he is in" [17]. This position facilitates the process of matching individuals. The other (the author) with the reader's personal meanings, which, in turn, launches a mechanism for constructing meanings. Here we rely on the principle of historicity of a person, his cultural certainty, developed in nonclassical hermeneutics (M. Heidegger, G.G. Gadamer). Pupils comprehend a work of art, are in search of answers to questions: "Why does the author think this way, feel, depict, and not otherwise? What caused this his position? Why exactly does this problem (topic) concern him so much?"

We have developed an algorithm of questions with which a student-reader, referring to the author's biography, his work, will be able to create a socio-psychological portrait of the author of the literary text. Let us present this algorithm:

1) Indicate the moments of the biography of the writer (poet) from your point of view that influenced the artist's choice of this problem (topic)?

2) What individual-personality traits of the author could affect the originality of the solution (embodiment) of a given problem (theme) in a work of art? What social connections (friendly, creative, family) of the writer, poet influenced on the creation of artistic images of the work? 
3) Give examples of the originality of the artistic language of the author, contributing to the embodiment of the artistic image and the disclosure of the idea of the work.

4) How are the social ideals and cultural values of the modern writer of the era reflected in the idea of a work of art? How did this problem (the theme) be embodied in the further work of this writer?

5) What are the authors touching on this problem (topic) in your work, in which work?

We note that, in our opinion, this form of work can rightfully be attributed to research, which is especially relevant for the modern model of education. This activity is important for enhancing students' self-determination in a situation of personal choice, strengthening personal positions in solving a life problem. Pupils are independent in their search for an answer to the question about the originality of the vision of the world by the author of a work of art, but they are equally responsible in interpreting the information they have to justify. This activity builds an internal coordinated system of worldviews through the mechanism of reflection.

The third stage of didactic communication - the activation of value-semantic relations "I am for myself" is associated with the formation of reflection and self-reflection skills in students: the ability to formulate and justify a contemporary actual problem, consonant with a work of art, to connect this problem with oneself, one's existential experience, and independently design way to solve the problem.

TABLE III RETURN TO MYSELF. REFLECTION AND SELFREFLECTION

\begin{tabular}{|c|c|c|c|}
\hline $\begin{array}{c}\text { Didactic } \\
\text { communication } \\
\text { and its purpose }\end{array}$ & Activities & Result & Methods \\
\hline $\begin{array}{l}\text { "I am for } \\
\text { myself": } \\
\text { activation of } \\
\text { reflection and } \\
\text { self-reflection }\end{array}$ & $\begin{array}{l}\text { Value- } \\
\text { semantic } \\
\text { modeling of } \\
\text { the author's } \\
\text { personality } \\
\text { (quasi- } \\
\text { communication } \\
\text { with the } \\
\text { represented } \\
\text { personality of } \\
\text { the author) }\end{array}$ & $\begin{array}{l}\text { The reader's } \\
\text { ability to } \\
\text { formulate and } \\
\text { justify a } \\
\text { contemporary } \\
\text { urgent problem, } \\
\text { consonant with the } \\
\text { work of art, to } \\
\text { independently } \\
\text { choose a way to } \\
\text { solve it }\end{array}$ & $\begin{array}{l}\text { Compilation } \\
\text { dialogue } \\
\text { with the } \\
\text { author on } \\
\text { the topic: } \\
\text { "What kind } \\
\text { of person to } \\
\text { be in this } \\
\text { world?" }\end{array}$ \\
\hline
\end{tabular}

When resolving the situation of life, personal selfdetermination carried out by students in the process of dialogue with the author, students need to receive emotional support from society, significant others. Such emotional support is possible through communication, through the exchange of feelings and thoughts with peers, a teacher. Thus, we consider it necessary to further develop communication in the activation of the value-semantic relationship "I am for others," which will allow the student to realize his individuality, the uniqueness of his vision of life.

\section{TABLE IV POLYLOGUE. FINDING YOURSELF}

\begin{tabular}{|c|c|c|c|}
\hline $\begin{array}{c}\text { Didactic } \\
\text { communication } \\
\text { and its purpose }\end{array}$ & Activities & Result & Methods, techniques \\
\hline $\begin{array}{l}\text { "I am for } \\
\text { Others": an } \\
\text { external } \\
\text { dialogue } \\
\text { (polylogue) } \\
\text { about the value } \\
\text { of a work of art } \\
\text { for itself and for } \\
\text { others }\end{array}$ & $\begin{array}{l}\text { Presentatio } \\
\mathrm{n} \text { of the } \\
\text { dialogue } \\
\text { with the } \\
\text { author in } \\
\text { the lesson; } \\
\text { Discussion } \\
\text { of dialogue } \\
\text { in talk } \\
\text { show } \\
\text { technology }\end{array}$ & $\begin{array}{l}\text { Schoolchild } \\
\text { ren getting } \\
\text { emotional } \\
\text { support of } \\
\text { peers, } \\
\text { teachers } \\
\text { ("significan } \\
\text { t Others") }\end{array}$ & $\begin{array}{l}\text { - Talk shows on the } \\
\text { topic: "Literature gives } \\
\text { immortality. } \\
\text { understood in the past } \\
\text { and as we understand, } \\
\text { " } \\
\text { - Discussion on the } \\
\text { topic: "How can } \\
\text { literature help people } \\
\text { learn to understand } \\
\text { each other?" }\end{array}$ \\
\hline
\end{tabular}

This stage of didactic communication proceeds in a situation. "I am a teacher, and I are students in the lesson". It is connected with the real situation of the external dialogue regarding the discussion of students' independent work (dialogues with the author of a work of art).

\section{CONCLUSION}

The hermeneutic approach in organizing the valuesemantic reading of literary and literary text in the process of didactic communication is aimed at understanding the literary text in dialogue with the author, other subjects of education (teacher, peers, parents). Dialogical relations of subjects of education are characterized by co-existence, that is, they are formed in the process of experiencing an artistic image, expression of personal involvement, value judgments about the content of a work of art. At the same time, the dialogical activity of the student perceiving the text is associated with questioning, modeling the author's attitudes, agreement or critical attitude towards them.

Particular attention is directed to the poetic-linguistic analysis of the literary text, revealing the logical and semantic structure of the text, the features of the language that reflect the image of the world and man in the minds of the author and the minds of the reader. The hermeneutic approach allows us to consider the value-semantic reading of a literary and artistic work as an intellectual and emotional process that combines the subjective experience and understanding of the reader into a single meaning-forming integrity, and a literary work as a discourse that facilitates the detection of personal meaning in the phenomena of artistic reality and in the process of communication with the author's meaning cultural life of society.

Such approach creates the basis for continuing humanitarian education at the level of higher education and further - in continuous self-education, when the pleasure of reading fiction becomes a value and indicates the manifestation of an emotional-value attitude to oneself, to others and to the world [18].

\section{References}

[1] L.V. Gorbul, "Experience of learning meaningful reading", Scientific and methodical journal: Educational Research, vol. 10, pp. 24-26, 2016. 
[2] L.N. Makarova, "Meaningful reading as a meta-subject result of the education of junior schoolchildren", Scientific electronic journal Meridian, vol. 4 (7), pp. 32-34, 2017.

[3] S.M. Mashaeva, "Specifics of learning to read schoolchildren", Herald of Scientific Conferences, vol. 4 (8), pp. 66-67, 2016.

[4] A.I. Savostyanov, "The education of the schoolchildren for meaningful reading", Methodist, vol. 6, pp. 58-60, 2019.

[5] D.Y. Pulatova, Sh. Honboboeva, "Effective Strategies in the Development of Reading Skills", Novoinfo.ru, vol. 99, pp. 95-98, 2019.

[6] E.A. Budoyan, "Hermeneutic approach to school philological education: aspect of educational results", Herald of Tver State University, Seri: Pedagogic and Psychology, vol. 3 (48), pp. 212-219, 2019.

[7] V.G. Reef, E.A. Poleva, "Reading preferences of modern fifth graders", Philological class, vol. 2 (48), pp. 52-56, 2017.

[8] N.M. Svirina, "Reading teens: study results and comparative analysis", Philological class, vol. 3 (49), pp. 64-72, 2017.

[9] W. Diltai, Introduction to the science of the spirit. A collection of works in 6 vol., vol. 1. Moscow: House of Intellectual Book, 2000, pp. 270-310.

[10] M. Heidegger, The path to language. Retrieved from: http://bibikhin.ru/put_k_yaziku
[11] G.G. Gadamer, Truth and Method: the basics of philosophical hermeneutics, translation from German. Moscow: Progress, 1988, pp 398-401.

[12] F. Schleiermacher, Hermeneutics, translation from German. St Petersburg: European House, 2004, 242 p.

[13] E.A. Zherebina, "Philological hermeneutics and the tradition of the German romantic school in linguistics", dis. ... kand. of Philologic Sciences. St. Petersburg, 2001, 180 p.

[14] L.A. Belyaeva, "Pedagogical activity in the context of the philosophy of education", Pedagogical education in Russia, vol. 3, pp. 11-15, 2010.

[15] M. Buber, Two images of faith, translation from German. Moscow: Republic, 1995, pp. 99-110.

[16] M. Heidegger, The source of artistic creation. Moscow: Academic Project, 2008, 528 p.

[17] I.G. Chugaeva, "Ontology of Contemporary Art Perception", Herald of the Chelyabinsk State Academy of Culture and Art, vol. 3 (47), pp. 71 77, 2016.

[18] E.V. Berezhnova, "Education as Value", Herald MGIMO, vol. 2, pp. 240-241, 2014. 